\title{
Is Speed Bumps Installation Panacea For Road Traffic Crash Prevention? An Evaluation of Selected Major Routes in Ondo, Southwestern Nigeria
}

\author{
Richard Paul Chukwugozi, \\ Federal Road Safety Corps, Akure, Nigeria
}

\begin{abstract}
The study examines the effect of speed bump installations along the selected major routes in Ondo and adopted three methods of investigation i.e. conducting Focus Group Discussions (FGDs), use of Questionnaire and referencing the FRSC Monthly RTCs Report/Quarterly Traffic Count Data.

The findings reveal that road traffic crash trend changed negatively in the selected routes after the speed bumps installation except in Akure-Ado route which might be owing to traffic diverting to alternative route where speed bumps are not installed. The findings also reveal that the majority of the participants do not support the speed bumps installation because of its negative implication in terms of damage to vehicle, human health as a result of impact and exposure of road users to criminal activities and a decline in traffic volume along the selected routes after the speed bumps installation except in Akure-Owo route which might be owing to either the cost implication of fuelling vehicles if the alternative route is used or there was no alternative route. People whose residences are in proximity to highways are in the habit of indiscriminately erecting bumps without recourse to specifications posed danger to both vehicles and road users. The fact that prevalent violations on these selected routes are speed dependant, it is suggested that the decisions agreed on in a communique issued on the $2^{\text {nd }}$ Stakeholders' forum on speed limiting device enforcement in Nigeria held in Abuja on Wednesday 04 September 2013 should be given strong political backing to achieve the goal of tackling speed factor.
\end{abstract}

Keywords: Speed, crash, bumps and installation

\section{Introduction}

Any road meant for public use and connecting two major cities or otherwise important destinations is referred to as a highway (Wikipedia, 2013). According to Oguara (2010), roads represent the major areas of investment in transportation and are the most dominant travel mode accounting for over $90 \%$ of passenger and goods transport in Nigeria. A road is supposed to provide dependable pathways for moving people and goods from one place to another without being death trap for the motoring public. Major modern highways that connect cities in populous developed and developing countries usually incorporate features intended to enhance the road's capacity, efficiency, and safety to various degrees. Such features include a reduction in the number of locations for user access, the use of dual carriageways with two or more lanes on each carriageway, and gradeseparated junctions with other roads and modes of transport.

In contrary, road traffic environment in Nigeria is scarcely provided with these inevitable and paramount components enumerated above. Rather, several kilometres of roads are characterised by bushy road environment; pot-holes; black-spots; poor visibility due to lack of street light at night. Traffic signs as well as traffic lights are not adequately available. Often time, pedestrians, cyclists and motorists compete jealously, especially in the urban centres, for right of way along highways. This is as a result of the poor planning structure of the roads (Odeleye, $13^{\text {th }}$ ICICT Workshop).

In the early days of road network development in Nigeria, vehicular traffic was sparingly distributed across the available road network. Growth in urbanization and in the number of vehicles has lead to increased traffic congestion in urban centers and increase in traffic crashes on road networks, which were never designed for the volumes and types of traffic that they are now to carry. There is also competition between different classes of road users coupled with poor road maintenance, bad and inadequate provision of road infrastructure. All these have contributed to the serious road safety problems in developing countries like Nigeria (Oyedepo \& Makinde, 2010).

Out of the four main modes of transportation, the one that puts people at the greatest risk of injury per kilometers travelled is road transportation (WHO, 2004) and the problem in road safety transcends the transport sector. The upward trend in vehicular traffic gave rise to increasing carnage on Nigerian roads. It is sad that the high mortality rate in Nigeria today is ascribable largely to such carnage, which surpasses deaths arising from ill-health, homicide, natural disasters or accidental circumstances (including industrial accident, fire outbreak and drowning). The morbidity and mortality burden in developing countries is rising due to a 
combination of factors, including rapid motorisation, poor road and traffic infrastructure as well as the behaviour of road users (Nantulya and Reich, 2002).

There are several underlying factors responsible for increasing road traffic crashes (RTCs) in Nigeria. Hunan factor constitutes about $90 \%$ of RTCs. Out of this percentage drivers' action or inactions accounts for about 80\% (FRSC, 2013b). According to FRSC (2013a), speed is one of the human factors behind crashes in which excessive speeding is defined as exceeding the speed limit while inappropriate speed is defined as driving at a speed unsuitable for the prevailing road and traffic conditions. Excess and inappropriate speeds are responsible for a high proportion of the mortality and morbidity that result from road crashes. In some low and middle income countries, speed is estimated to be the main contributory factor in about 50 percent of all crashes.

The issue of speed has been identified by WHO as a key risk factor in road traffic injuries, influencing both the risk of a crash as well as the severity of the injuries that result from crashes. The relationship between speed and injury severity is particularly critical for vulnerable road users such as pedestrians and cyclists. Higher driving speeds increase the risk and severity of crashes. This risk is particularly high for vulnerable users, including pedestrians and cyclists, who are present in large numbers in urban areas. When the impact speed in a collision is $30 \mathrm{~km} / \mathrm{h}$, a pedestrian's likelihood of being fatally injured is approximately $10 \%$; at 50 $\mathrm{km} / \mathrm{h}$, it jumps to over $75 \%$ (Ashton, 1981).

The perception of speeding on highways is probably the most persistent problem facing all and sundry and people whose residences are in proximity to highways perceive vehicles are being driven at high speeds and conclude that the speeds would decrease if speed bumps were installed. Speed bumps are installations of raised pavement on roads or parking lots intended to slow vehicular traffic and tend to exhibit inconsistent design parameters from one installation and another. They are generally three to six inches in height and one to three feet in length across the roadway or driving area which are intended to reduce vehicle speeds up to 5 miles per hour $(8 \mathrm{~km} / \mathrm{hr})$ and not recommended for public roads. As more and more speed bumps are installed, the question of the legality of this measure is becoming irrelevant.

Speed bump installations in Nigeria especially Ondo State emanated from the need to bring the vulnerable road users especially pedestrians out of the vulnerability mode. Hence, the extracts below culled from the daily newspapers further explain better the genesis of speed bump installations in the State. The papers read thus:

\section{"Ondo youths protest killings by drivers"}

"For the second day running, hundreds of youths blocked the Iju/Itaogbolu-Ado Ekiti Express-way, protesting the alleged killing of three persons, including two youths and an aged woman, by hit-and-run drivers within three days. The irate youths, who dug a trench across the expressway, vowed to remain on the road until speed guide, in form of bumps, are made on the road by relevant government agencies."

"The Vanguard" Newspaper, November 14, 2013.

\section{"Villagers block highway to protest youth's death in Ondo"}

"Villagers at Ogbese, a suburb of Akure Ondo State yesterday stormed the highways to protest the killing of a youth in the ever busy Akure-Owo Expressway by a commercial bus driver. Commuters and other motorists were stranded for several hours due to the traffic gridlock caused by the protesters. The deceased was crushed to death by a commercial bus when he was trying to cross to the other side of the road."

"The Sun news Online", August 15, 2013.

\section{"Trailer kills teenager in Ondo community, youths go on rampage"}

"There was heavy traffic yesterday, along Owo-Akungba Road linking the South West and the Federal Capital Territory as youth of Oba, Akoko community erected several barricades on the highway in protest of a 14-year-old teenage youth killed by a trailer. In protest, the irate youth made bonfires on the roads within the town and chanted war songs, while calling on relevant authorities to construct speed breakers along the highway to prevent recurrence."

"The Dailypost Nigeria online newspaper", January 6, 2014.

In many instances, speed bumps were installed instantaneously without considering the characteristics of vehicles plying the highways, neither the nature of the road environment nor safety of other road users. The speed bump installations are in most cases carried out due to yearning of people whose residences are in proximity to the highways regardless of laws guiding the construction of highways. Therefore, this study evaluated the effect of speed bumps installation along the selected major routes in Ondo. 


\section{Objective Of The Study}

This study is to evaluate the effect of speed bump installations along the selected major routes in Ondo, Southwestern Nigeria

\section{Specific objectives:}

$>$ To analyse the crash rate before and after specific sections of the selected routes were installed with speed bumps,

$>$ To determine the acceptable level of the speed bump installations among the road users plying those routes and,

> To compare the traffic volume along the selected major routes before and after the installations.

\section{Research Questions}

$>$ Does the speed bumps installation bring about change in the crash trend along the selected major routes?

$>$ What is the extent to which the speed bump installations are acceptable among the categories of road users?

$>$ Has the vehicular traffic pattern change along the selected routes since the installation of the speed bumps?

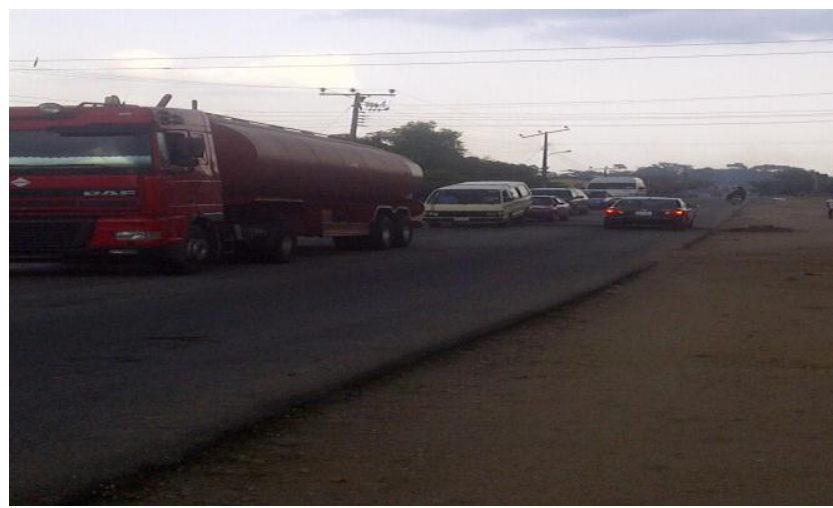

Fig.1: Categories of vehicle negotiating the speed bumps along Ikare-Owo Route

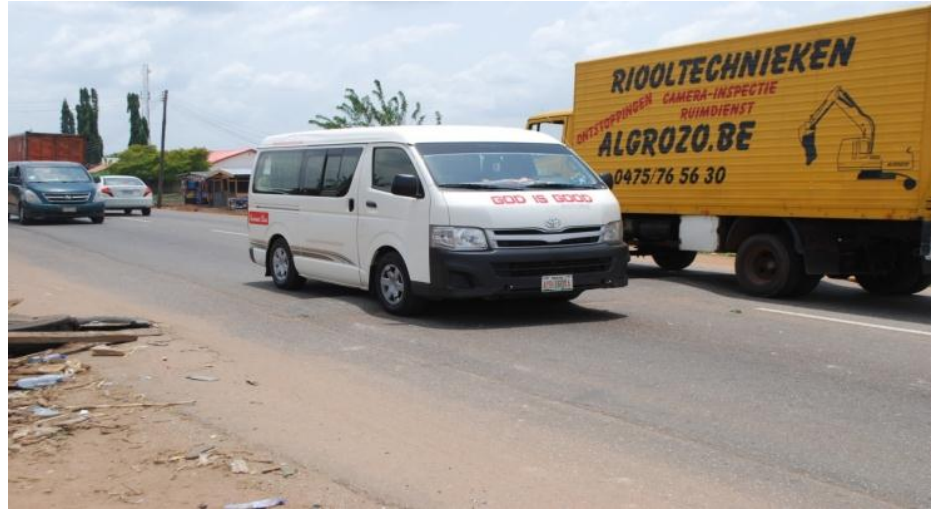

Fig.2: Categories of vehicle negotiating the speed bumps along Akure-Owo Route

\section{Rearch Setting And Methodology}

The study area is Ondo State which was created out of former Ondo Province of Former Western State in 1976. It is bounded by Kwara and Kogi State in the North, Edo State to the East, Delta State to the South East, Osun and Ogun States to the West and the Bight of Benin of the Atlantic Ocean to the South. Agriculture is the main stay of the economy of the people and they produce both cash and food crops. The state is primarily inhabited by the Yoruba people with a tradition of living in towns. The landmass of the State is 14,606 square $\mathrm{km}$ with a population of 3,441,024 (NPC, 2006). There are 12 major routes which connected the State to other parts of the country. The strategically selected major routes are the Akure-Owo, Akure-Ado and Ikare-Owo due to the installation of speed bumps along these routes in recent time.

The study was largely exploratory and limited to the evaluation of three (3) selected routes in Ondo. The routes assessed were those with bumps installation. It involved different categories of road users excluding children (minor) plying the routes. The specific locations used for the study are Oba-Akoko in Ikare - Owo, Ogbese in Akure-Owo and Iju in Akure-Ado routes. Traders, Transport workers and other people were also interviewed and their views/suggestions may provide useful ideas for intervention. 
To make the study an-all inclusive one, three methods of investigation were used. This becomes imperative because not all of the research population were literate, and some of the issues demanded a different approach. The methods used are Focal Group Discussions (FGDs), questionnaire and Monthly RTCs Report/ Quarterly Traffic Count Data.

100 questionnaires were distributed randomly among the road users plying the selected routes in Ondo comprising drivers (Private and Commercial), passengers, pedestrians, traffic officers, and other users of the roads. Participation of respondents are voluntary and consent was given before the instruments were applied. Two (2) FGDs each of traders, transport workers and other road users who have one way or the other ply these selected routes and their views were thought to be paramount in evaluating the effect of speed bumps installation on the motoring public. Responses from the FGDs were reported verbatim to complement the quantitative data generated from cross sectional survey. A simple percentage Statistical analysis was employed as well as a content analysis of the Focal Group Discussions.

\section{Results And Discussion}

The results of the study are presented below and grouped according to the research questions.

\section{Question one}

Does the speed bumps installation bring about change in the crash trend along the selected major routes?

To make adequate evaluation of the selected routes in terms of RTCs and fatality, a comparative analysis of the RTC Report for 3/6 months before and after the dates of the speed bumps installation were employed.

$$
\begin{aligned}
& \text { KEY } \\
& \text { DOT - Dangerous Overtaking } \\
& \text { LOC - Loss of Control } \\
& \text { SPV - Speed Limit Violation } \\
& \text { OBS - Road Obstruction }
\end{aligned}
$$

$$
\begin{aligned}
& \text { BC - Bicycle } \\
& \text { MC - Motorcycle } \\
& \text { TC - Tricycle }
\end{aligned}
$$

SUV - Seat Belt Use Violation

P/UP - Pick Up

TRL - Trailer

TRK - Truck

R.P - Reference Point

RTV - Route Violation m - male
f - female
c - children

DAD - Driving under

Alcohol/Drug Influence

TYV - Tyre Violation

PWR- Poor Weather

FTQ - Fatigue

COMACE- Corps Marshal \&

Chief Executive

BFL - Brake Failure

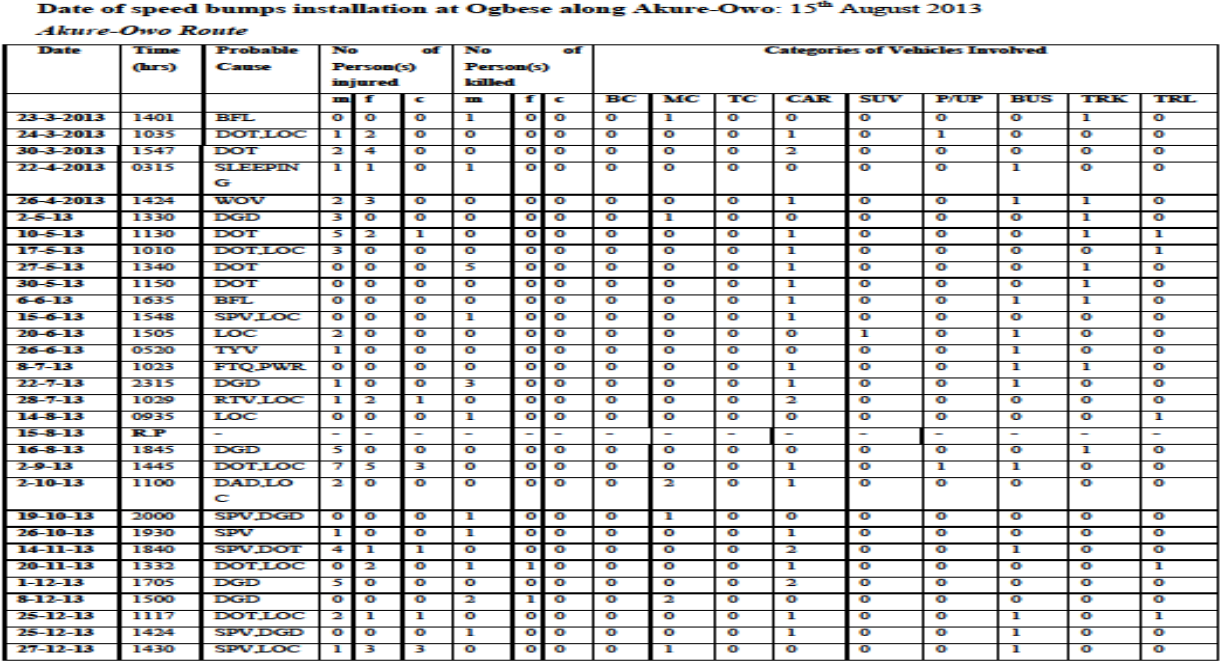




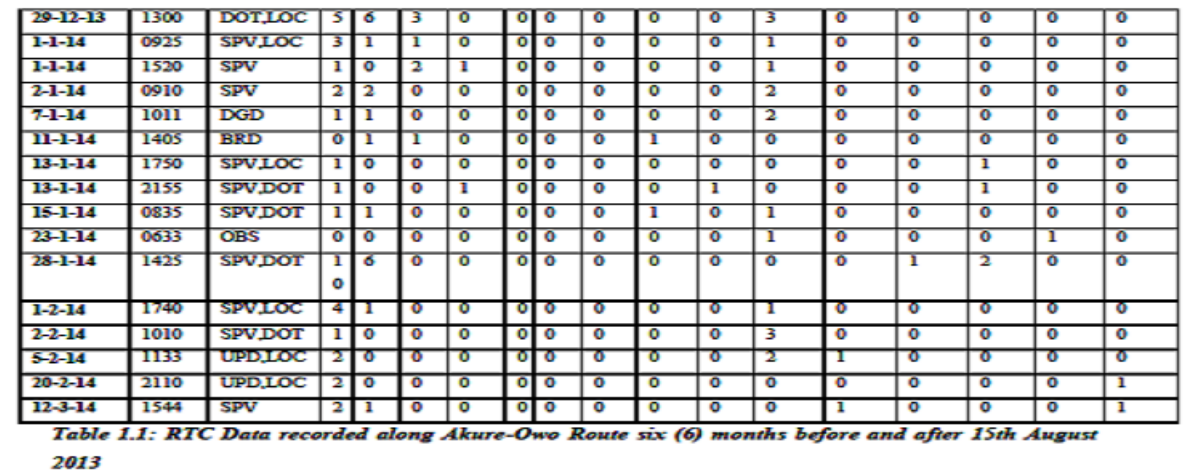

The total RTCs that occurred six months before the speed bumps installation amounted to 18 while the RTCs that occurred six months after summed up to 28 . There was $55.5 \%$ increase in RTCs six months after the speed bumps installation. Truck/Trailer accounted for 10 of 18 (55.5\%) RTCs six months before speed bumps installation and 6 of $28(21.4 \%)$ RTCs six months after speed bumps installation. This revealed that RTCs resulting from Truck/Trailer decline by $34.1 \%$ six months after the installation. Truck/Trailer alone caused 7 of $12(58 \%)$ fatalities before speed bumps installation and 2 of $10(20 \%)$ fatalities after speed bumps installation.

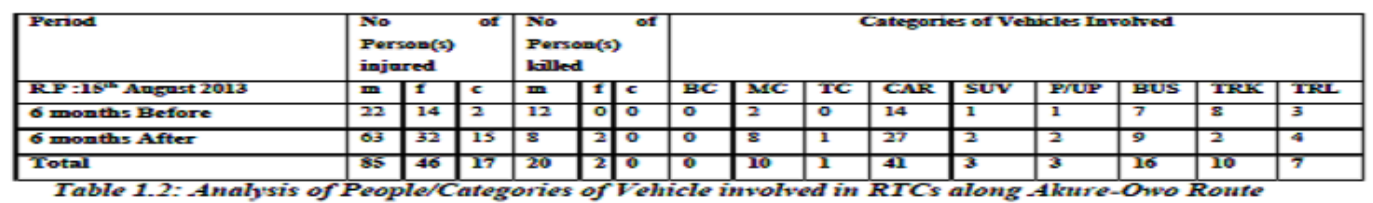

Severity Index of RTCs six months before the speed bumps installation is determined as follows;

Number of RTCs $=18$

Number of Death $=12$

Number of Injured $=22+14+2=38$

Casualty figure $=12+38=50$

Fatality Rate $=$ Number of Death $/$ Number of RTCs

$$
={ }^{12} / 18
$$

Casualty Rate $=$ Casualty figure $/$ Number of RTCs

$$
=50 / 18
$$

'Severity Index $=$ Fatality Rate $/$ Casuality Rate

$$
\begin{aligned}
& =12 / 18 / 50 / 18 \\
& ={ }^{12} / 50
\end{aligned}
$$

Severity Index (A) $\quad=0.24$

Severity Index of RTCs six months after the speed bumps installation is determined as follows;

Number of RTCs $=28$

Number of Death $=10$

Number of Injured $=63+32+15=110$

Casualty figure $=10+110=120$

Fatality Rate $=$ Number of Death $/$ Number of RTCs

$$
=10 / 28
$$

Casualty Rate $=$ Casualty figure $/$ Number of RTCs 


$$
=120 / 28
$$

Severity Index $=$ Fatality Rate $/$ Casuality Rate

$$
\begin{aligned}
& =10 / 28 / 120 / 28 \\
& ={ }^{10} / 120
\end{aligned}
$$

Severity Index $(B) \quad=0.083$

The Severity Index of RTCs six months before the Speed Bumps Installation is higher than six months after i.e. A>B.

\begin{tabular}{|c|c|c|c|c|}
\hline Cause of RTC & Frequency Before & Frequency After & Total & Percent (\%) \\
\hline BFN & 2 & - & $\mathbf{2}$ & 2.98 \\
\hline DOT & 6 & 9 & $\mathbf{1 5}$ & 22.38 \\
\hline LOC & 5 & 11 & $\mathbf{1 6}$ & 22.85 \\
\hline Sleeping & 1 & - & $\mathbf{1}$ & 1.49 \\
\hline WOV & 1 & - & $\mathbf{1}$ & 1.49 \\
\hline DGD & 2 & 6 & $\mathbf{8}$ & 11.94 \\
\hline SPV & 1 & 15 & $\mathbf{1 6}$ & 22.85 \\
\hline TYV & 1 & - & $\mathbf{1}$ & 1.49 \\
\hline DAD & - & 1 & $\mathbf{1}$ & 1.49 \\
\hline UPD & - & 2 & $\mathbf{2}$ & 2.98 \\
\hline BRD & - & 1 & $\mathbf{1}$ & 1.49 \\
\hline OBS & - & 1 & $\mathbf{1}$ & 1.49 \\
\hline FTQ & 1 & - & $\mathbf{1}$ & 1.49 \\
\hline PWR & 1 & - & $\mathbf{1}$ & 1.49 \\
\hline
\end{tabular}

Table 1.3: Analysis of the RTC causal factors along Akure-Owo Route

DOT, LOC and SPV accounted for $68 \%$ of total causal factors (violations) along Akure-Owo Route from $15^{\text {th }}$ February 2013 to $15^{\text {th }}$ February 2014 and the offences are inter-related as over speeding could make the control of the vehicle get out of hand. The result almost corroborated with the COMACE's statement during the second stakeholders' forum in Abuja that speed violation accounted for about 65 per cent of causative factors of road crashes and fatalities within the last seven months of 2013.

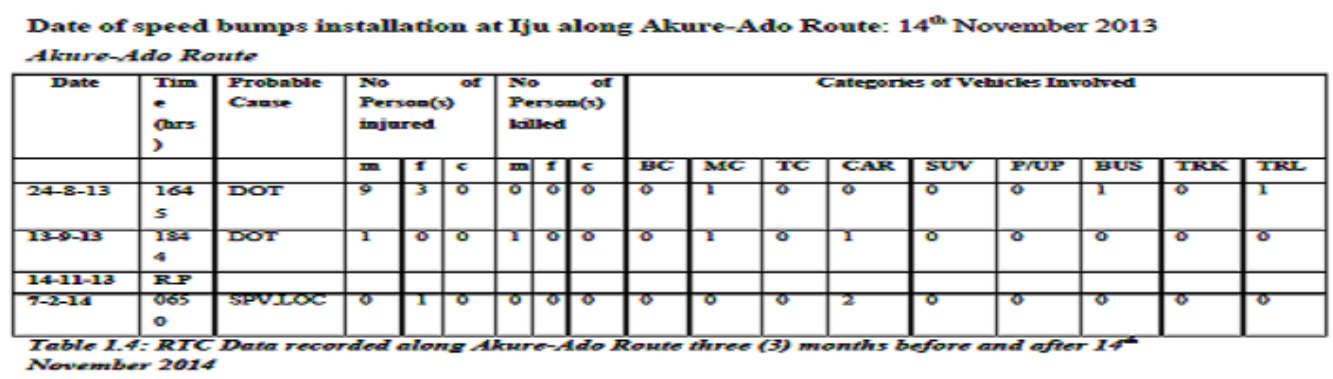

The total RTCs that occurred three months before the speed bumps installation amounted to 2 while the RTC(s) that occurred three months after was only one. The observed sharp drop in road crash on this route might be as a result of traffic diverting to alternative route where speed bumps are not installed. There was $50.0 \%$ reduction in RTCs three months after the speed bumps installation. Truck/Trailer accounted for 1 of 3 (33.3\%) RTCs three months before speed bumps installation while no RTC was caused by Truck/Trailer three months after. This revealed that RTCs resulting from Truck/Trailer decline by $33.3 \%$ three months after the installation.

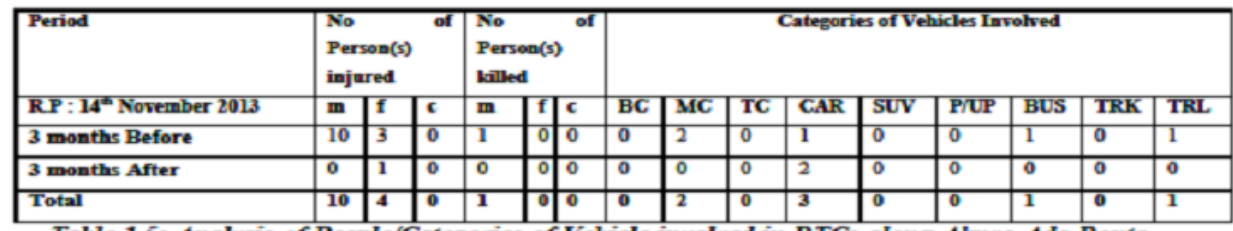

Table 1.5: Analysis of People/Categories of Velicle involved in RTCs along Akure-Ado Route 
Severity Index of RTCs three months before the speed bumps installation is determined as follows;

Number of RTCs $=2$

Number of Death $=1$

Number of Injured $=10+3+0=13$

Casualty figure $=1+13=14$

Fatality Rate $=$ Number of Death $/$ Number of RTCs

$$
={ }^{1} / 2
$$

Casualty Rate $=$ Casualty figure $/$ Number of RTCs

$$
={ }^{14} / 2
$$

'Severity Index $=$ Fatality Rate $/$ Casuality Rate

$$
\begin{aligned}
& =1 / 2 / 14 / 2 \\
& ={ }^{1 /} / 14
\end{aligned}
$$

Severity Index $(\mathbf{C}) \quad=0.071$

Severity Index of RTCs three months after the speed bumps installation is determined as follows;

Number of RTCs $=1$

Number of Death $=0$

Number of Injured $=0+1+0=1$

Casualty figure $=0+1=1$

Fatality Rate $=$ Number of Death $/$ Number of RTCs

$$
=0 / 1
$$

Casualty Rate $=$ Casualty figure $/$ Number of RTCs

$$
=^{1} / 1
$$

Severity Index $=$ Fatality Rate $/$ Casuality Rate

$$
\begin{aligned}
& =0 / 1 / 1 / 1 \\
& ={ }^{0} / 1
\end{aligned}
$$

Severity Index (D) $\quad=0$

The Severity Index of RTCs three months before the Speed Bumps Installation is higher than six months after i.e. $\mathrm{C}>\mathrm{D}$.

\begin{tabular}{|c|c|c|c|}
\hline Cause of RTC & Frequency Before & Frequency After & Total \\
\hline DOT & 2 & - & $\mathbf{2}$ \\
\hline LOC & - & 1 & $\mathbf{1}$ \\
\hline SPV & - & 1 & $\mathbf{1}$ \\
\hline
\end{tabular}

Table 1.6: Analysis of the RTC causal factors along Akure-Ado Route

DOT, LOC and SPV are causal factors (violations) along Akure-Ado Route from $14^{\text {th }}$ August 2013 to $14^{\text {th }}$ February 2014. 


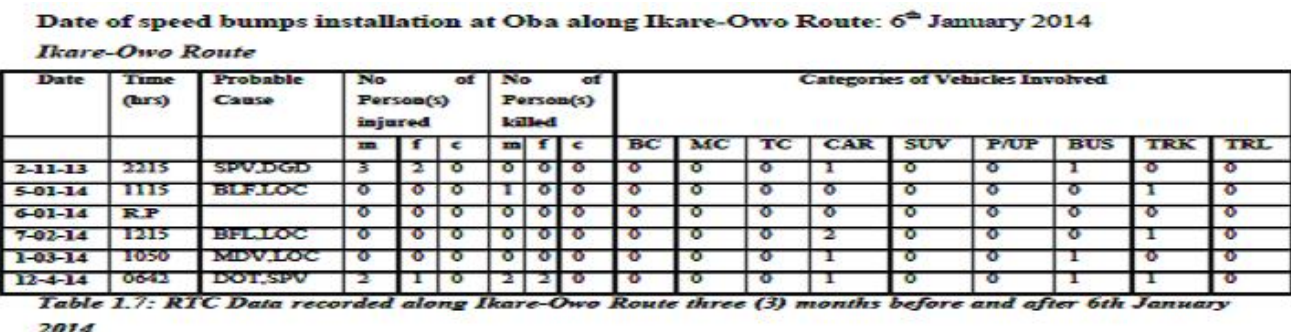

The total RTCs that occurred three months before the speed bumps installation amounted to two (2) while the RTC(s) that occurred three months after was three (3) in number. There was $50.0 \%$ increase in RTCs three months after the speed bumps installation. Truck/Trailer accounted for 1 of $2(50.0 \%)$ RTCs three (3) before speed bumps installation while RTC caused by Truck/Trailer three months after accounted for 2 of 3 (66.7\%) RTCs. This indicated that RTCs resulting from Truck/Trailer rise by $16.7 \%$ three months after the installation. Truck/Trailer caused the only one fatality which occurred three months before speed bumps installation and the only four fatalities that occurred three months after speed bumps installation.

\begin{tabular}{|c|c|c|c|c|c|c|c|c|c|c|c|c|c|c|c|}
\hline \multirow{2}{*}{\begin{tabular}{|l|} 
Period \\
RP :6 January 2014 \\
\end{tabular}} & \multicolumn{3}{|c|}{$\begin{array}{l}\text { No } \\
\text { Person(s) of } \\
\text { injured }\end{array}$} & \multicolumn{3}{|c|}{$\begin{array}{l}\text { No } \quad \text { of } \\
\text { Person(s) } \\
\text { killed }\end{array}$} & \multicolumn{9}{|c|}{ Categories of vehicles Involved } \\
\hline & $\mathbf{m}$ & $\mathbf{f}$ & c & $\mathbf{m}$ & f & c & BC & MC & TC & CAR & SUv & P/UP & BUS & TRK & TRI \\
\hline 3 months Before & 3 & 2 & 0 & 1 & 0 & 0 & 0 & o & 0 & 1 & 0 & 0 & 1 & 1 & 0 \\
\hline 3 months After & 2 & $T$ & 0 & 2 & 2 & 0 & 0 & 0 & 0 & 4 & 0 & 0 & 2 & 2 & $\sigma$ \\
\hline Total & 5 & 3 & 0 & 3 & 2 & 0 & 0 & 0 & 0 & 5 & 0 & 0 & 3 & 3 & 0 \\
\hline
\end{tabular}

Severity Index of RTCs three months before the speed bumps installation is determined as follows;

Number of RTCs $=2$

Number of Death $=1$

Number of Injured $=3+2+0=5$

Casualty figure $=5+1=6$

Fatality Rate $=$ Number of Death $/$ Number of RTCs

$$
=1 / 2
$$

Casualty Rate $=$ Casualty figure $/$ Number of RTCs

$$
=6 / 2
$$

'Severity Index $=$ Fatality Rate $/$ Casuality Rate

$$
\begin{aligned}
& =1 / 2 / 6 / 2 \\
& =1 / 6
\end{aligned}
$$

Severity Index $(\mathbf{E}) \quad=0.166$

Severity Index of RTCs three months after the speed bumps installation is determined as follows;

Number of RTCs $=3$

Number of Death $=4$

Number of Injured $=2+1+0=3$

Casualty figure $=3+4=7$

Fatality Rate $=$ Number of Death $/$ Number of RTCs

$$
=4 / 3
$$

Casualty Rate $=$ Casualty figure $/$ Number of RTCs

$$
=7 / 3
$$


'Severity Index $={ }^{\text {Fatality Rate }} /$ Casuality Rate

$$
\begin{aligned}
& =4 / 3 / 7 / 3 \\
& =4 / 7
\end{aligned}
$$

Severity Index $(\mathbf{F}) \quad=0.571$

The Severity Index of RTCs three months before the Speed Bumps Installation is lower than three months after i.e. $E<F$.

\begin{tabular}{|c|c|c|c|}
\hline Cause of RTC & Frequency Before & Frequency After & Total \\
\hline DOT & - & 1 & $\mathbf{1}$ \\
\hline LOC & 1 & 2 & $\mathbf{3}$ \\
\hline SPV & 1 & 1 & $\mathbf{2}$ \\
\hline MDV & - & 1 & $\mathbf{1}$ \\
\hline BFL & 1 & 1 & $\mathbf{2}$ \\
\hline DGD & 1 & - & $\mathbf{1}$ \\
\hline
\end{tabular}

Table 1.9: Analysis of the RTC causal factors along Ikare-Owo Route

DOT, LOC and SPV accounted for $60 \%$ of total causal factors (violations) along Ikare-Owo Route from $6^{\text {th }}$ October 2013 to $6^{\text {th }}$ April 2014.The report within this period also indicates that DOT and LOC which are directly linked to speeding were equally risk factors. Summed together, excessive speeding remains the biggest obstacle to the Corps 2014 Goals of cutting down crashes by 15 per cent and fatalities by 25 per cent.

\section{Question two}

What is the extent to which the speed bump installations are acceptable among the categories of road users?

Table2.1: Distribution of Questionnaire along the major routes

\begin{tabular}{|c|c|c|}
\hline Selected Routes & Lengths of Road (Km) & Questionnaire \\
\hline Akure-Owo & 23 & 40 \\
\hline Akure-Ado & 43 & 30 \\
\hline Ikare- Owo & 30 & 30 \\
\hline Total & $\mathbf{9 6}$ & $\mathbf{1 0 0}$ \\
\hline
\end{tabular}

Table 2.2: Respondents' Usage of the road

\begin{tabular}{|l|l|c|c|}
\hline Item & Measurement & Frequency & Percent (\%) \\
\hline \multirow{2}{*}{$\begin{array}{l}\text { How often do you ply this } \\
\text { route? }\end{array}$} & Always & 58 & 58 \\
\cline { 2 - 4 } & Occasionally & 38 & 38 \\
\cline { 2 - 4 } & Rarely & 4 & 4 \\
\hline
\end{tabular}

\begin{tabular}{|c|c|c|c|c|}
\hline & Item & Measurement & Frequency & Percent (\%) \\
\hline \multirow[b]{2}{*}{ a } & \multirow{2}{*}{$\begin{array}{l}\text { Do you feel comfortable when } \\
\text { you observed that speed } \\
\text { bumps have been constructed } \\
\text { along this route? }\end{array}$} & Yes & 42 & 42 \\
\hline & & No & 58 & 58 \\
\hline \multirow{4}{*}{$\mathrm{b}$} & \multirow{4}{*}{$\begin{array}{l}\text { What do you suggest was the } \\
\text { reason for the construction? }\end{array}$} & Incessant killing of pedestrians & 15 & 15 \\
\hline & & To reduce vehicular speed & 33 & 33 \\
\hline & & Crash reduction/prevention & 22 & 22 \\
\hline & & I don't know & 30 & 30 \\
\hline \multirow{3}{*}{$\mathrm{c}$} & \multirow[t]{3}{*}{$\begin{array}{l}\text { Has the construction meet up } \\
\text { with the purpose? }\end{array}$} & Yes & 22 & 22 \\
\hline & & No & 48 & 48 \\
\hline & & I don't know & 30 & 30 \\
\hline \multirow[t]{2}{*}{$\mathrm{d}$} & \multirow{2}{*}{$\begin{array}{l}\text { Do you support the } \\
\text { intervention? }\end{array}$} & Yes & 37 & 37 \\
\hline & & No & 63 & 63 \\
\hline
\end{tabular}

Table 2.3: Perception of Respondents towards the Speed Bumps Installation 


\section{The purpose of the speed bumps installation}

The installation of the speed bumps can be as a result of many $f$ actors. Most of the participants at the focus group discussions, however, cited that vehicular speed as the main factor responsible for the erection. As one trader in one of the interviews submits,

The reason for the construction of speed bumps is to reduce the over-speeding of motor passing the road which automatically reduce the rate of accidents on our road

A participant in one of the focus groups also asserted:

This is to reduce speed along the highway when approaching busy area like markets, schools etc

These responses are typical of the respondents. Although vehicular speed is considered as the prime factor, other factors mentioned are crash reduction/prevention, which is also reflected in the aforementioned response, and spate incessant killing of pedestrians. From the survey conducted along the selected routes, 22\% of participants opined that the construction met up with the purpose but with emerging issues.

\section{Implication of the erection on road transportation}

With reference to the public perception on the impact of the speed bumps erection on road transportation in Ondo, more than half of the respondents stressed that the bumps suddenly cause tear and wear of vehicles. Responses such as

Its implication on total time spent on the journey apart. It in the long run causes deterioration (at rates more than normal) of the vehicle mechanically which invariably translates to high maintenance cost, attest to this.

Focus groups discussions among significant others in the environment confirm the negative implications of the installation.

Erection of bumps on the highway cannot stop accident; hence it can truly lead to more accident. Just imagine what happen in a situation where a strange driver enter with high speed into bumps that had just been erected

(FGD with Transport Workers)

It must be noted that erection of bumps do waste time and cause more havoc to the road users. I felt mad when my relative had a miscarriage along Akure-Ado road at Ita-ogbolu bump erection

(FGD with Other Road Users) in Ghana:

These corroborate with the statement of Dr. Acquaye at a road safety awards for drivers held recently

Some of the bumps were too sharp and high and were the cause of frequent tyre punctures and damage to shock absorbers could be the cause of low back pains and neck pains reported at the hospitals.

It was reported that Dr. Acquaye brought a polythene bag full of bolts, knots and rivets picked at one of the bumps sites close to the Regional Hospital in Ghana to prove the damage which such bumps caused to vehicles.

From a study conducted by Omidiji \& Ibitoye (2010), it was stated that some criminals used stones, tyre rims and wood laced with nails to stop vehicles by setting them on roads as traps to deflate the tyres that ran over them thereby unleash terror on the helpless victims. This provides a temporal machinery to perpetrate crime unlike speed bumps installation which is permanently position to aid criminality unknowingly as posited by one of the FGDs.

Speed bumps erection brings time delay and if care is not taken armed robbers will molest commuters along the road side.

(FGD with Other Road Users)

The findings from the survey reveal that the erection has negative implication in terms of damage to vehicle, human health as a result of impact and exposure of road users to criminal activities.

\section{Acceptable Level of the Intervention}

The finding from the study showed that $63 \%$ of the respondents do not support the intervention, which was evident in a statement made during the FGD session by one of the participants as follows: The speed bumps erection is not vehicle-friendly and causes back and neck pains of vehicle occupants 
(FGD with Other Road Users)

It was observed that the $37 \%$ of those that supported the erection are mainly traders who ply their trade in the built up areas (crash prone) and have witnessed some incidents in the areas. Be that it may, other road users' perception on the issue need to be taken into cognisance for critical analysis and necessary recommendations.

\section{Question 3} bumps?

Has the vehicular traffic pattern change along the selected routes since the installation of the speed

To determine the change in the vehicular traffic pattern along the selected major routes in Ondo, Quarterly Traffic Count Data before and after the installation dates of the speed bumps were compared.

- AKURE-OWO ROUTE

- Date of Speed Bumps Installation: $15^{\text {th }}$ August 2013

- $2^{\text {nd }} \& 3^{\text {rd }}$ Quarter Traffic Count Data of year 2013 were considered

\section{$2^{\mathrm{ND}}$ QUARTER 2013 TRAFFIC COUNT COLLATION}

SECTOR: RSI1.2 AKURE

ROUTE: AKURE-OWO

COUNTING POINT: FEDERAL GOVERNMENT GIRLS' COLLEGE

WEATHER: RAINING

DIRECTION INDICATORS FROM: AKURE

To: owo

\begin{tabular}{|c|c|c|c|c|c|c|c|c|c|c|c|c|c|}
\hline $\begin{array}{l}\text { TMIE } \\
\text { INTERVAL }\end{array}$ & $B C$ & MC & TC & $\begin{array}{l}\text { CAR } \\
\text { (P) }\end{array}$ & PIUP & TXI & $\begin{array}{l}\text { OMAN } \\
\text { BUS }\end{array}$ & $\mathrm{LUT}$ & LOR/RUCK & TRL & \begin{tabular}{|l|l} 
TANKFR \\
\end{tabular} & OTHER & TOTAL \\
\hline $0600-0700$ & 0 & 28 & 0 & 43 & 21 & 31 & 47 & 2 & 22 & 13 & 21 & 0 & 228 \\
\hline $0700-00000$ & $T$ & 35 & 0 & 47 & 27 & 39 & 31 & T & 30 & 19 & 27 & 0 & 277 \\
\hline $0800-0900$ & 0 & 48 & $\overline{0}$ & 53 & 33 & 40 & 61 & 0 & 35 & 23 & 29 & 0 & 322 \\
\hline $0900-1000$ & 0 & 36 & 0 & 64 & 37 & 37 & 78 & 1 & 47 & 30 & 32 & 0 & 362 \\
\hline $1000-1100$ & 0 & 34 & $T$ & 73 & 31 & 35 & 88 & 0 & 43 & 33 & 37 & 0 & 375 \\
\hline $1100-1200$ & 0 & 41 & 1 & 89 & 29 & 38 & 92 & 0 & 37 & 38 & 35 & 1 & 401 \\
\hline $1200-1300$ & 0 & 30 & 0 & 91 & 28 & 11 & 108 & 1 & 24 & 40 & 39 & 0 & 372 \\
\hline $1300-1400$ & $\sigma$ & 27 & 4 & 106 & 18 & 15 & III & 0 & 26 & 39 & 27 & 0 & 375 \\
\hline $1400-1500$ & 0 & 17 & 0 & 117 & 25 & 34 & 126 & 0 & 31 & 35 & 28 & 0 & 413 \\
\hline $1500-1600$ & 1 & 21 & 6 & 102 & 27 & 22 & 131 & 0 & 39 & 27 & 40 & 0 & 416 \\
\hline $1600-1700$ & 0 & 22 & 0 & 131 & 21 & 20 & 105 & 2 & 40 & 21 & 43 & 0 & 405 \\
\hline $17000-1800$ & 0 & 34 & 0 & 139 & 27 & 33 & 718 & 0 & 42 & 30 & 37 & 0 & 460 \\
\hline TOTAL & 2 & 373 & 12 & 1055 & 324 & 355 & 1116 & 7 & 416 & 348 & 395 & 1 & 4604 \\
\hline
\end{tabular}

DIRECTION INDICATORS FROM: OWO

TO: AKURE

\begin{tabular}{|c|c|c|c|c|c|c|c|c|c|c|c|c|c|}
\hline \begin{tabular}{|l|} 
TMII \\
INTERVAL
\end{tabular} & $B C$ & MC & TC & $\begin{array}{l}\text { CAR } \\
\text { (P) }\end{array}$ & $\mathrm{P} / \mathrm{UP}$ & TXI & $\begin{array}{l}\text { OMNI } \\
\text { BUS }\end{array}$ & $\mathrm{LUx}$ & LOR/TKUCK & TRL & \begin{tabular}{|l} 
TANKKR \\
\end{tabular} & OTHER & TOTAL \\
\hline $0600-0700$ & 0 & 28 & 0 & 87 & 11 & 39 & 50 & 1 & 27 & 18 & 17 & 0 & 278 \\
\hline $0700-00000$ & 0 & 32 & 0 & 93 & 15 & 40 & 35 & 0 & 30 & 21 & 20 & 0 & 306 \\
\hline $0800-0900$ & 0 & 22 & 1 & 92 & 12 & 47 & 61 & $\overline{0}$ & 31 & 29 & 21 & $\overline{0}$ & 316 \\
\hline $0900-1000$ & 1 & 31 & 1 & 85 & 27 & 49 & 66 & 0 & 15 & 32 & 22 & 0 & 32 \\
\hline $1000-1100$ & 0 & 15 & 3 & 72 & 24 & 37 & 87 & 0 & 25 & 30 & 23 & 12 & 328 \\
\hline $1100-1200$ & 3 & 23 & 0 & 62 & 28 & 22 & 98 & 10 & 13 & 28 & 20 & 0 & 307 \\
\hline $1200-1300$ & 0 & 21 & 2 & 63 & 24 & 21 & 105 & 15 & 12 & 25 & 19 & 5 & 312 \\
\hline $1300-1400$ & 0 & 25 & 0 & 75 & 2 & 17 & III & 0 & 10 & 26 & 21 & 10 & 297 \\
\hline $1400-1500$ & 0 & 26 & 5 & 70 & 11 & 30 & 87 & 0 & 15 & 22 & 27 & 3 & 296 \\
\hline $1500-1600$ & 1 & 19 & 0 & 78 & 15 & 28 & 54 & 16 & 23 & 27 & 30 & 0 & 291 \\
\hline $1600-1700$ & 0 & 25 & 2 & 92 & 25 & 25 & 67 & 1 & 37 & 31 & 33 & 2 & 340 \\
\hline $1700-18000$ & 0 & 23 & $T$ & 63 & 29 & 18 & 71 & $T$ & 36 & 35 & 32 & 0 & 309 \\
\hline TOTAL & 5 & 290 & 15 & 932 & 223 & 373 & 912 & 44 & 274 & 324 & 285 & 32 & 3709 \\
\hline
\end{tabular}


$3^{\text {KD }}$ QUARTER 2013 Traffic Count Collation

SECTOR: RS11.2 AKURE

ROUTE: AKURE-OWO

COUNTING POINT: FEDERAL GOVERNMENT GIRLS' COLLEGE

WEATHER: RAINING

DIRECTION INDICATORS FROM: AKURE

TO: OwO

\begin{tabular}{|c|c|c|c|c|c|c|c|c|c|c|c|c|c|}
\hline $\begin{array}{l}\text { TMIE } \\
\text { INTERVAL }\end{array}$ & $B C$ & MC & TC & $\begin{array}{l}\text { CAR } \\
\text { (P) }\end{array}$ & PUPP & TXI & $\begin{array}{l}\text { OMNI } \\
\text { BUS }\end{array}$ & LUX & LOR/TRUCK & \begin{tabular}{|l|l|} 
TRLL \\
\end{tabular} & TANKFR & OTHER & TOTAL \\
\hline $0600-0000$ & 0 & 40 & 2 & 250 & 20 & 100 & 30 & 3 & 10 & 3 & 0 & 0 & 485 \\
\hline $0700-09000$ & 0 & 45 & 0 & 200 & 29 & 150 & 63 & 7 & $\frac{5}{5}$ & 5 & 0 & $\overline{0}$ & 506 \\
\hline $0800-0900$ & 4 & 40 & 2 & 100 & 10 & 92 & 71 & 4 & 21 & 9 & 34 & 3 & 390 \\
\hline $0900-1000$ & 7 & 20 & 0 & 95 & 43 & 142 & 122 & 2 & 35 & 12 & 15 & 15 & 508 \\
\hline $1000-1100$ & $T$ & 35 & 3 & 127 & 78 & 113 & 77 & $T$ & 43 & 0 & 33 & 23 & 536 \\
\hline $1100-1200$ & 3 & 20 & 0 & 160 & 67 & 134 & 89 & 0 & 34 & 2 & 45 & 32 & 586 \\
\hline $1200-1300$ & 5 & 22 & 0 & 120 & 55 & 145 & 54 & 4 & 24 & 0 & 38 & 33 & 500 \\
\hline $1300-1400$ & 3 & 45 & 4 & 150 & 45 & 197 & 34 & $T$ & 31 & 15 & 24 & 46 & 595 \\
\hline $1400-1500$ & 0 & 30 & 0 & 162 & 93 & 78 & 87 & $\overline{0}$ & 23 & 0 & 37 & 24 & 534 \\
\hline $1500-1600$ & 3 & 40 & 0 & 234 & 32 & 134 & 80 & 5 & 43 & 1 & 28 & 17 & 617 \\
\hline $1600-1700$ & 2 & 30 & 1 & 168 & 78 & 110 & 126 & 2 & 21 & 20 & 23 & 35 & 636 \\
\hline $1700-1800$ & 0 & 35 & 0 & 123 & 12 & 32 & 41 & $\overline{0}$ & 2 & $\overline{2}$ & 21 & 0 & 208 \\
\hline TOTAL & 28 & 422 & 14 & 1889 & 562 & 1427 & 896 & 31 & 292 & 69 & 298 & 228 & 6156 \\
\hline
\end{tabular}

DIRECTION INDICATORS FROM: OWO

TO: AKURE

\begin{tabular}{|c|c|c|c|c|c|c|c|c|c|c|c|c|c|}
\hline \begin{tabular}{|l|} 
TMII \\
INTERVAL
\end{tabular} & $B C$ & MC & TC & $\begin{array}{l}\text { CAR } \\
\text { (P) }\end{array}$ & PIUP & TXI & \begin{tabular}{|l} 
OMNI \\
BUS
\end{tabular} & $\mathrm{LUX}$ & LOR/RUCK & TKL & TANKFR & OTHER & TOTAL \\
\hline $0600-0700$ & 0 & 40 & 0 & 250 & 19 & 69 & 10 & 0 & 10 & 12 & 20 & 0 & 430 \\
\hline $0700-05000$ & 0 & 39 & 0 & 300 & 27 & 71 & 39 & 1 & 13 & 0 & 19 & 15 & 544 \\
\hline $0800-09000$ & 3 & 29 & 6 & 79 & 12 & $\pi$ & 36 & 2 & 13 & 0 & 35 & 0 & 306 \\
\hline 0900-1000 & 1 & 35 & 0 & 70 & 56 & 92 & 82 & 3 & 36 & 10 & 33 & 3 & 421 \\
\hline $1000-1100$ & 4 & 20 & 0 & 140 & 55 & 76 & 114 & 0 & 31 & 0 & 42 & 25 & 527 \\
\hline $1100-12000$ & 0 & 15 & 4 & 150 & 36 & 81 & 61 & 0 & 21 & 0 & 39 & 7 & 434 \\
\hline $1200-1300$ & 6 & 25 & 0 & 134 & 45 & 76 & 76 & 2 & 43 & 20 & 42 & 3 & 472 \\
\hline $1300-1400$ & 1 & 30 & 0 & 114 & 65 & 134 & 23 & 3 & 23 & 0 & 34 & 10 & 437 \\
\hline $1400-1500$ & 2 & 27 & 8 & 156 & 72 & 45 & 39 & 2 & 45 & 0 & 31 & 9 & 456 \\
\hline \begin{tabular}{|l|}
$1500-16000$ \\
\end{tabular} & 4 & 45 & $\overline{0}$ & 190 & 45 & 124 & 65 & $\overline{2}$ & 34 & 13 & 55 & 15 & 592 \\
\hline $1600-1700$ & 1 & 47 & 0 & 156 & 23 & 76 & 79 & 0 & 17 & 0 & 41 & 9 & 49 \\
\hline $1700-18000$ & 0 & 37 & 3 & 112 & 9 & 25 & 23 & 3 & 7 & 16 & 17 & 0 & 252 \\
\hline TOTAL & 22 & 409 & $\overline{21}$ & 1851 & 484 & 940 & 687 & 18 & $\overline{313}$ & 7 & 406 & 96 & 5320 \\
\hline
\end{tabular}

\begin{tabular}{|c|c|c|c|c|c|c|}
\hline & \multicolumn{3}{|c|}{$2^{\text {nd }}$ Quarter } & \multicolumn{3}{|c|}{$3^{\text {rd }}$ Quarter } \\
\hline Vehicle & Akr/Owo & Owo/Akr & Total & Akr/Owo & Owo/Akr & Total \\
\hline BC & 2 & 5 & 7 & 28 & 22 & 50 \\
\hline MC & 373 & 290 & 663 & 422 & 409 & 831 \\
\hline TC & 12 & 15 & 27 & 14 & 21 & 35 \\
\hline Car & 1055 & 932 & 1987 & 1889 & 1851 & 3740 \\
\hline P/UP & 324 & 223 & 547 & 562 & 484 & 1046 \\
\hline Taxi & 355 & 373 & 728 & 1427 & 940 & 2367 \\
\hline Omni Bus & 1116 & 912 & 2028 & 896 & 687 & 1583 \\
\hline Luxury & 7 & 44 & 51 & 31 & 18 & 49 \\
\hline Lor/Truck & 416 & 274 & 690 & 292 & 313 & 605 \\
\hline Trailer & 348 & 324 & 672 & 69 & 71 & 140 \\
\hline Tanker & 395 & 285 & 680 & 298 & 408 & 706 \\
\hline Other & 1 & 32 & 33 & 228 & 96 & 324 \\
\hline Total & 4404 & 3709 & 8113 & 6156 & 5320 & 11476 \\
\hline
\end{tabular}

Total traffic counted bi-directionally during the 2013 Second Quarter Traffic Count (before the speed bumps were installed) $=8113$

Total hour spent $=12$

Average vehicular traffic per hour $=$

total vehicular traffic counted bi-directionally $/$ Total hour spent 
Average vehicular traffic per hour $=8113 / 12$

$=676$ vehicles per hour

Total traffic counted bi-directionally during the 2013 Third Quarter Traffic Count (after the speed

bumps were installed) $=11476$

Total hour spent $=12$

Average vehicular traffic per hour $=$

total vehicular traffic counted bi-directionally $/$ Total hour spent

Average vehicular traffic per hour $=11476 / 12$

$\begin{aligned} & =956 \text { vehicles per hour } \\ \% \Delta \text { in vehicular traffic pattern }= & (11476-8113) / 8113 \times 100 \%\end{aligned}$

$$
=3363 / 8113 \times 100 \%
$$

$=41.45 \%$

There was $45 \%$ increase in traffic volume when the 2013 Second Quarter Traffic Count Data (before the speed bumps installation) and Third Quarter Traffic Count Data (after the speed bumps installation) collated with respect to Akure-Owo route were compared. The increase might be owing to either the cost implication of fuelling vehicles if the motorists took alternative route or there was no alternative route.

Comparing analytically the data obtained from the Traffic Counted during the 2013 Second and Third Quarter in respect of heavy goods vehicle as follows;

Total heavy good vehicle for the 2013 Second Quarter Traffic Count $=2,042$

Total heavy good vehicle for the 2013 Third Quarter Traffic Count $=1,451$

$\% \Delta$ in vehicular traffic pattern $=(1451-2042) / 2042 \times 100 \%$

$$
=-591 / 2042 \times 100 \%
$$

$$
=-28.94 \%
$$

There was $28.94 \%$ decline in heavy good vehicle that ply the route for the periods under review. This might be owing to hostile nature of the communities along the route especially when crash involving drivers of heavy goods vehicle occurred. The peak period in the 2013 Second and Third Quarter Traffic Count fell in the evening which might have increase the probability of pedestrians (such as children) involving in road traffic crashes in those communities along the route since majority of them were already back from school.

- AKURE-ADO ROUTE

- Date of Speed Bumps Installation: $15^{\text {th }}$ November 2013

- $3^{\text {rd }} \& 4^{\text {th }}$ Quarter Traffic Count Data of year, 2013 were considered 


\section{$3^{\text {KD }}$ QUARTER 2013 TRAFFIC COUNT COLLATION}

SECTOR: RS11.2 AKURE

ROUTE: AKURE-ADO

COUNTING POINT: 100M FROM ADO GARAGE

WEATHER: RAINING

DIRECTION INDICATORS FROM: AKURE

TO: ADO

\begin{tabular}{|c|c|c|c|c|c|c|c|c|c|c|c|c|c|}
\hline $\begin{array}{l}\text { TWIE } \\
\text { INIERVAL }\end{array}$ & $B C$ & $\mathrm{MCC}$ & TC & $\begin{array}{l}\text { CAK } \\
\text { (P) }\end{array}$ & PNOP & TXII & $\begin{array}{l}\text { OMAN } \\
\text { BUS }\end{array}$ & todx & LON/HKUCE & Ther & TANKEF & Orifiek & TOIAL \\
\hline $06000-0700$ & 0 & 12 & 0 & 50 & 3 & 30 & 15 & 0 & 3 & 0 & 3 & 0 & 12 \\
\hline $0700-05000$ & 0 & 5 & 0 & 65 & 12 & 69 & 19 & 0 & 9 & 0 & 10 & 0 & $1 \circledast$ \\
\hline $0800-0900$ & 2 & 30 & 2 & 110 & 15 & 95 & 77 & 6 & 25 & 5 & 30 & 3 & 400 \\
\hline $0900-1000$ & 3 & 15 & 0 & 100 & 45 & 145 & 125 & 3 & 40 & 0 & 19 & 10 & 500 \\
\hline $1000-1100$ & 7 & 17 & $\overline{0}$ & 130 & 80 & 120 & 80 & $\overline{0}$ & 40 & $\overline{0}$ & 35 & 25 & 534 \\
\hline $1100-1200$ & 3 & 20 & 0 & 165 & 70 & 138 & 90 & 0 & 34 & 9 & 47 & 35 & 611 \\
\hline $1200-1300$ & $T$ & 10 & 10 & 130 & 60 & 150 & 60 & 3 & 25 & 0 & 40 & 40 & 531 \\
\hline $1300-1400$ & 4 & 15 & $\overline{0}$ & 152 & 47 & 200 & 40 & 2 & 30 & 7 & 27 & 15 & 539 \\
\hline $1400-1500$ & 3 & 20 & 0 & 163 & 98 & 80 & 90 & 0 & 27 & 0 & 40 & 10 & 531 \\
\hline $1500-16000$ & 4 & 15 & 0 & 230 & 37 & 137 & 85 & 6 & 45 & 0 & 31 & 5 & 595 \\
\hline $1600-17000$ & 0 & 30 & 3 & 170 & 80 & 115 & 130 & 3 & 27 & 4 & 29 & 42 & 635 \\
\hline $1700-1800$ & 0 & 35 & 0 & 130 & 20 & 39 & 120 & 0 & 4 & 0 & 25 & 10 & 383 \\
\hline TOTAL & 29 & 224 & 15 & 1595 & 569 & 1338 & 931 & 27 & 311 & 25 & 338 & 195 & 5597 \\
\hline
\end{tabular}

DIRECTION INDICATORS FROM: ADO

TO: AKURE

\begin{tabular}{|c|c|c|c|c|c|c|c|c|c|c|c|c|c|}
\hline $\begin{array}{l}\text { TMIE } \\
\text { INTERVAL }\end{array}$ & $B C$ & MC & TC & $\begin{array}{l}\text { CAR } \\
\text { (P) }\end{array}$ & P/UP & TXI & $\begin{array}{l}\text { OANI } \\
\text { BUS }\end{array}$ & $\mathbf{L I X}$ & LOK/TKUCK & TKL & TANKER & OTHER & TOTAL \\
\hline $06000-0700$ & 0 & 25 & 0 & 100 & 15 & & 50 & 3 & 15 & 3 & 12 & 0 & 307 \\
\hline $0700-05000$ & 0 & 39 & 8 & 120 & 13 & 80 & 65 & 1 & 21 & 0 & 11 & 10 & 360 \\
\hline $0800-0900$ & 3 & 20 & 0 & 85 & 17 & 72 & 60 & 4 & 15 & 10 & 35 & 0 & 324 \\
\hline $0900-1000$ & 4 & II & 0 & 75 & 60 & 97 & 87 & 7 & 45 & 0 & 25 & 235 & 436 \\
\hline $1000-1100$ & $\overline{0}$ & 10 & 2 & 150 & 65 & 80 & 117 & 4 & 47 & $\overline{0}$ & 40 & 0 & 515 \\
\hline $1100-1200$ & 0 & 25 & 0 & 140 & 60 & 85 & 65 & 3 & 20 & 9 & 50 & 10 & 467 \\
\hline $1200-1300$ & 0 & 5 & 0 & 120 & 50 & 80 & 50 & 4 & 40 & 0 & 45 & 20 & 414 \\
\hline $1300-1400$ & 1 & 17 & 12 & 158 & 69 & 140 & 30 & 4 & 20 & 0 & 28 & 19 & 498 \\
\hline $1400-1500$ & 4 & 19 & 0 & 170 & 75 & 50 & 60 & 1 & 29 & 7 & 42 & 5 & 462 \\
\hline $1500-1600$ & 2 & 10 & 0 & 195 & 50 & 125 & 50 & 2 & 40 & 0 & 35 & 37 & 546 \\
\hline $1600-1700$ & 0 & 35 & 10 & 157 & 30 & 80 & 115 & T & 20 & 12 & 32 & 40 & 532 \\
\hline $1700-1800$ & 2 & 40 & 0 & 120 & 15 & 30 & 105 & 1 & 10 & 0 & 29 & 0 & 352 \\
\hline TOTAL & 16 & 256 & 32 & 1590 & 519 & 994 & 854 & 37 & 322 & 43 & 334 & 166 & 5213 \\
\hline
\end{tabular}




\title{
$4^{\text {TH }}$ QUARTER 2013 TRAFFIC COUNT COLLATION
}

\author{
SECTOR: RSII.2 AKURE \\ ROUTE: AKURE-ADO \\ COUNTING POINT: \\ WEATHER: HARMATTAN \\ DATE: $16^{\text {TH }}$ DEC., 2013
}

DIRECTION INDICATORS FROM: AKURE

TO: ADO

\begin{tabular}{|c|c|c|c|c|c|c|c|c|c|c|c|c|}
\hline $\begin{array}{l}\text { TIME } \\
\text { INTEKVAL }\end{array}$ & $B C$ & MC & TC & $\begin{array}{l}\text { CAR } \\
\text { (P) }\end{array}$ & P/UP & TXI & $\begin{array}{l}\text { OMNI } \\
\text { BUS }\end{array}$ & Lex & LOK/TRUCK & TKL/TANKER & OTHER & TOTAI \\
\hline $0600-0700$ & 0 & 45 & 0 & 115 & 111 & 140 & 20 & 0 & 9 & 12 & 0 & 452 \\
\hline $0700-03000$ & $\sigma$ & 65 & 0 & 105 & 102 & 125 & 65 & 0 & 10 & 15 & 0 & 487 \\
\hline $0800-0900$ & $\overline{0}$ & 55 & 1 & 120 & 56 & 11 & 47 & $\overline{0}$ & 30 & 27 & 4 & 351 \\
\hline $0900-1000$ & 1 & 28 & 0 & 145 & 91 & 127 & 108 & 0 & 35 & 20 & 6 & 561 \\
\hline $1000-1100$ & 0 & 25 & 0 & 100 & 84 & 117 & 30 & 1 & 25 & 18 & 9 & 409 \\
\hline $1100-1200$ & $\overline{0}$ & 24 & $\overline{2}$ & 95 & 60 & 102 & 45 & $\overline{0}$ & 10 & 19 & $\overline{2}$ & 359 \\
\hline $1200-1300$ & 1 & 47 & 0 & 80 & 65 & 100 & 50 & 0 & 17 & 21 & 1 & 382 \\
\hline $1300-1400$ & 0 & 35 & 0 & 75 & 80 & 103 & 51 & 1 & 8 & 25 & 3 & 381 \\
\hline $1400-1500$ & $\sigma$ & 33 & 4 & 35 & 74 & 90 & 47 & 0 & 20 & 20 & 3 & 348 \\
\hline $1500-1600$ & 1 & 50 & 0 & 105 & 30 & 85 & 29 & 0 & 36 & 27 & 0 & 363 \\
\hline $1600-1700$ & 2 & 20 & 3 & 68 & 35 & 95 & 30 & 1 & 27 & 16 & 4 & 301 \\
\hline $1700-13000$ & 0 & 25 & 0 & 70 & 40 & 97 & 47 & 0 & 30 & 19 & 0 & 323 \\
\hline TOTAI & 5 & 452 & $\overline{10}$ & 1133 & 828 & 1192 & 569 & $\overline{3}$ & 257 & 239 & 34 & 4722 \\
\hline
\end{tabular}

DIRECTION INDICATORS FROM: ADO

TO: AKURE

\begin{tabular}{|c|c|c|c|c|c|c|c|c|c|c|c|c|}
\hline $\begin{array}{l}\text { TIMI } \\
\text { INTERVAL }\end{array}$ & $B C$ & MC & TC & $\begin{array}{l}\text { CAR } \\
\text { (P) }\end{array}$ & P,UP & TXI & \begin{tabular}{|l} 
OMNI \\
BUS
\end{tabular} & Lex & LOK/TKUCK & TKL/TANKFR & OTHER & TOTAL \\
\hline $0600-0700$ & 0 & 30 & 0 & 120 & 102 & 130 & 10 & 0 & 0 & 0 & 0 & 412 \\
\hline $0700-08500$ & 0 & 70 & 0 & 115 & 115 & 140 & 15 & 0 & 0 & 0 & 0 & 455 \\
\hline $0800-09000$ & 0 & 65 & 2 & 125 & 100 & 102 & 65 & $\overline{0}$ & 10 & 16 & 9 & 494 \\
\hline $0900-1000$ & 0 & 65 & 0 & 130 & so & 105 & 11 & 0 & 15 & 39 & 10 & 425 \\
\hline $1000-1100$ & 1 & 50 & 0 & 110 & 80 & 117 & 40 & 0 & 20 & 35 & 0 & 453 \\
\hline $1100-12000$ & 0 & 40 & 3 & 80 & 65 & 120 & 45 & 0 & 30 & 9 & 0 & 392 \\
\hline $1200-1300$ & 1 & 20 & 0 & 79 & 30 & 135 & 50 & 0 & 35 & 25 & 6 & 401 \\
\hline $1300-1400$ & 0 & 27 & 0 & 57 & 27 & 140 & 52 & 0 & 26 & 20 & 0 & 369 \\
\hline $1400-15000$ & 2 & 25 & 4 & 100 & 35 & 145 & 49 & 0 & 10 & 22 & 0 & 412 \\
\hline $1500-1600$ & 0 & 40 & 0 & 75 & 10 & 90 & 20 & 0 & 15 & 30 & 3 & 283 \\
\hline $1600-1700$ & 4 & 45 & 0 & 60 & 20 & 100 & 35 & 0 & 17 & 11 & 1 & 293 \\
\hline $1700-18000$ & $\sigma$ & 25 & 0 & 75 & 30 & 30 & 50 & 0 & 12 & 13 & 0 & 255 \\
\hline TOTAL & 8 & 522 & 9 & 1126 & 704 & 1374 & 442 & 0 & 190 & 220 & 29 & 4624 \\
\hline
\end{tabular}

\begin{tabular}{|l|c|c|c|c|c|c|}
\hline & \multicolumn{3}{|c|}{$\mathbf{3}^{\text {rd }}$ Quarter } & \multicolumn{3}{c|}{$\mathbf{4}^{\text {th }}$ Quarter } \\
\hline Vehicle & Akr/Ado & Ado/Akr & Total & Akr/Ado & Ado/Akr & Total \\
\hline BC & 29 & 16 & $\mathbf{4 5}$ & 5 & 8 & $\mathbf{1 3}$ \\
\hline MC & 224 & 256 & $\mathbf{4 8 0}$ & 452 & 522 & $\mathbf{9 7 4}$ \\
\hline TC & 15 & 32 & $\mathbf{4 7}$ & 10 & 9 & $\mathbf{1 9}$ \\
\hline Car & 1595 & 1590 & $\mathbf{3 1 8 5}$ & 1133 & 1126 & $\mathbf{2 2 5 9}$ \\
\hline P/UP & 569 & 519 & $\mathbf{1 0 8 8}$ & 828 & 704 & $\mathbf{1 5 3 2}$ \\
\hline Taxi & 1338 & 994 & $\mathbf{2 3 3 2}$ & 1192 & 1374 & $\mathbf{2 5 6 6}$ \\
\hline Omni Bus & 931 & 854 & $\mathbf{1 7 8 5}$ & 569 & 442 & $\mathbf{1 0 1 1}$ \\
\hline Luxury & 27 & 37 & $\mathbf{6 4}$ & 3 & 0 & $\mathbf{3}$ \\
\hline Lor/Truck & 311 & 322 & $\mathbf{6 3 3}$ & 257 & 190 & $\mathbf{4 4 7}$ \\
\hline Trailer/Tanker & $25 / 338$ & $43 / 384$ & $\mathbf{6 8} / 722$ & 239 & 220 & $\mathbf{4 5 9}$ \\
\hline Other & 195 & 166 & $\mathbf{3 6 1}$ & 34 & 29 & $\mathbf{6 3}$ \\
\hline Total & $\mathbf{5 5 9 7}$ & $\mathbf{5 2 1 3}$ & $\mathbf{1 0 8 1 0}$ & $\mathbf{4 7 2 2}$ & $\mathbf{4 6 2 4}$ & $\mathbf{9 3 4 6}$ \\
\hline
\end{tabular}

Total traffic counted bi-directionally during the 2013 Third Quarter Traffic Count (before the speed bumps were installed) $=10810$

Total hour spent $=12$ 
Average vehicular traffic per hour $=$

total vehicular traffic counted bi-directionally $/$ Total hour spent

Average vehicular traffic per hour $=10810 / 12$

$=901$ vehicles per hour

Total traffic counted bi-directionally during the 2013 Fourth Quarter Traffic Count (after the speed bumps were installed) $=9346$

Total hour spent $=12$

Average vehicular traffic per hour $=$

total vehicular traffic counted bi-directionally / Total hour spent

Average vehicular traffic per hour $=9346 / 12$

$\% \Delta$ in traffic pattern $=\left(\begin{array}{c}=779 \text { vehicles per hour } \\ (9346-10810) / 10810 \times 100 \%\end{array}\right.$

$$
=-1464 / 10810 \times 100 \%
$$

$=-13.54 \%$

There was $13.54 \%$ decline in traffic volume when the 2013 Third Quarter Traffic Count Data (before the speed bumps installation) and Fourth Quarter Traffic Count Data (after the speed bumps installation) collated with respect to Akure-Ado route were compared. The decrease might be owing to motorists' alternative route of getting to their various destinations. The peak period in the 2013 Third and Fourth Quarter Traffic Count Data fell in the evening which might be owing to traders returning from markets where their produce are sold.

- IKARE-OWO ROUTE

- Date of Speed Bumps Installation: $6^{\text {th }}$ January 2014

- $20134^{\text {th }}$ Quarter Traffic Count Data and $20141^{\text {st }}$ Quarter Traffic Count Data were considered $4^{\text {TH }}$ QUARTER 2013 IRAFFIC COUNT COLLATION

SECTOR: RSI1.2 AKURE

ROUTE: IKARE-OWO

COUNTING

DATE: $17^{\text {th }}$ December 2013

DIRECTION INDICATORS FROM: IKARE

TO: Owo

\begin{tabular}{|c|c|c|c|c|c|c|c|c|c|c|c|c|}
\hline $\begin{array}{l}\text { mix } \\
\text { nNTEVal }\end{array}$ & BC & MC & TC & $\begin{array}{l}\text { CAR } \\
\text { (P) }\end{array}$ & $P$ PIPP & TXI & \begin{tabular}{|l|} 
OMNI \\
BUS
\end{tabular} & $\mathbf{L} \mathbf{x}$ & LOK/TKUCK & TKL/ANKCTR & OTHER & Total \\
\hline $0600-0100$ & 8 & 45 & 0 & 41 & 42 & II & 44 & 1 & 15 & 22 & 10 & 231 \\
\hline 700000000 & 0 & 40 & 0 & 32 & $2 \pi$ & 4 & 33 & 0 & 26 & 7 & 13 & 23 \\
\hline $0800-05 \times 1$ & 8 & 43 & 2 & 37 & 33 & 0 & 29 & 2 & 14 & 9 & $\overline{16}$ & 207 \\
\hline $0900-10000$ & 0 & 34 & & 48 & 37 & 9 & 45 & 0 & 6 & $\overline{\text { II }}$ & $\overline{18}$ & 208 \\
\hline $1000-1100$ & 2 & 33 & 0 & 52 & 42 & 21 & 32 & 0 & 9 & 12 & 21 & 29 \\
\hline $1100-1200$ & 7 & 31 & 8 & 55 & 52 & 8 & 45 & $T$ & 14 & $\overline{13}$ & 23 & 20 \\
\hline $1200-1300$ & 4 & 27 & 0 & 75 & 33 & 30 & 23 & 0 & 12 & 9 & 12 & 25 \\
\hline $1300-1+400$ & 0 & 21 & 0 & 94 & 28 & 0 & 45 & 0 & 35 & 6 & 8 & 287 \\
\hline $1+000-1500$ & $T$ & 45 & 0 & H & 32 & 12 & 24 & 0 & 16 & 5 & $\pi$ & 228 \\
\hline $1300-1600$ & 0 & 46 & 0 & 69 & 52 & 27 & 43 & 0 & 9 & 6 & 9 & 261 \\
\hline $1600-17000$ & 0 & 34 & 0 & $\bar{n}$ & 46 & 21 & 31 & 0 & 3 & 4 & 6 & 219 \\
\hline $1700-1800$ & 8 & 42 & 8 & 38 & 29 & 9 & 35 & 8 & 15 & 3 & 2 & 193 \\
\hline TOTAL & 7 & 441 & 2 & 757 & 454 & 152 & 469 & 4 & 176 & 10 & 16 & 2715 \\
\hline
\end{tabular}


DIRECTION INDICATORS FROM: OWO

\begin{tabular}{|c|c|c|c|c|c|c|c|c|c|c|c|c|}
\hline $\begin{array}{l}\text { TMII } \\
\text { DTrEvat }\end{array}$ & $B C$ & MC & TC & $\begin{array}{l}\text { CAR } \\
\text { (P) }\end{array}$ & $\mathrm{P} / \mathrm{PP}$ & IXI & $\begin{array}{l}\text { OANI } \\
\text { Bus }\end{array}$ & Lex & LOR/RUCK & TRL/ANGER & OTHER & TOTAL \\
\hline $0600-0700$ & 0 & 38 & 0 & 63 & 45 & 10 & 40 & 8 & 19 & 6 & 16 & 265 \\
\hline $0700-05000$ & 0 & 33 & 0 & 60 & 48 & 21 & 20 & 3 & 22 & 8 & 4 & 219 \\
\hline $0800-0900$ & 8 & 35 & 0 & 35 & 27 & 13 & 29 & 3 & 4 & 5 & 7 & 160 \\
\hline $0900-1000$ & 0 & 30 & 0 & 35 & 29 & 35 & 42 & 9 & 18 & II & 3 & 252 \\
\hline $1000-110$ & 8 & 31 & 0 & 45 & 8 & 23 & 43 & 4 & 6 & 1 & 13 & 174 \\
\hline HWO-12\% & 8 & का & 8 & 62 & 3 & II & 36 & 8 & 16 & 3 & 21 & 254 \\
\hline $1200-1300$ & 0 & 33 & 0 & 43 & 15 & 9 & 25 & 12 & 7 & 15 & 4 & 165 \\
\hline $1300-1400$ & 0 & 33 & 0 & 40 & 11 & 14 & 23 & 16 & 12 & 8 & 6 & 183 \\
\hline $1400-1500$ & 8 & 35 & 8 & 30 & 15 & $T$ & 36 & II & 4 & 3 & 3 & 166 \\
\hline $1500-16000$ & 0 & 43 & 0 & 36 & 30 & 12 & 40 & 8 & 3 & 8 & 4 & 204 \\
\hline $1600-1700$ & 0 & 36 & 0 & 50 & 18 & 17 & 34 & 0 & 7 & II & 2 & 175 \\
\hline $17000-1500$ & 0 & का & 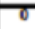 & 34 & 24 & 20 & 38 & 13 & 14 & 7 & J & 215 \\
\hline TOTAL & 8 & 514 & $\overline{0}$ & 613 & 307 & 192 & 406 & 9 & 132 & 85 & 86 & 202 \\
\hline
\end{tabular}

$1^{\text {st }}$ QUARTER 2014 TRAFFIC COUNT COLLATION

SECTOR: RS11.2 AKURE

ROUTE: IKARE-OWO

COUNTING POINT:

WEATHER:

DATE:

DIRECTION INDICATORS FROM: OWO

TO: IKARE

\begin{tabular}{|c|c|c|c|c|c|c|c|c|c|c|c|c|}
\hline $\begin{array}{l}\text { TMEE } \\
\text { INTEKVAL }\end{array}$ & $B C$ & MC & TC & $\begin{array}{l}\text { CAR } \\
\text { (P) }\end{array}$ & PIUP & TXI & $\begin{array}{l}\text { OMNI } \\
\text { BUS }\end{array}$ & Letx & LOR/TKUCK & TRL/TANKFER & OTHER & TOTAL \\
\hline $0600-0700$ & 0 & 21 & 0 & 11 & 3 & 19 & 11 & 0 & 18 & 12 & 3 & 98 \\
\hline $0700-05000$ & 8 & 37 & 0 & 29 & 4 & 26 & 29 & 3 & 21 & 18 & 0 & 167 \\
\hline $0800-0900$ & 1 & 41 & 1 & 36 & 18 & 29 & 19 & 6 & 11 & 28 & 4 & 193 \\
\hline $0900-1000$ & 0 & 39 & 0 & 41 & 3 & 22 & 31 & 3 & 28 & 31 & 6 & 204 \\
\hline $1000-1100$ & 0 & 23 & 0 & 32 & 6 & 36 & 38 & 0 & 31 & II & 0 & 177 \\
\hline $1100-1200$ & 0 & 29 & 0 & 18 & 16 & II & 21 & 8 & 18 & 26 & 3 & 151 \\
\hline $1200-1300$ & 0 & 26 & 0 & 23 & 12 & 19 & 34 & 4 & 26 & 17 & 7 & 168 \\
\hline $1300-1400$ & 0 & 31 & o & 18 & 9 & 28 & 41 & 2 & 21 & 36 & 3 & 189 \\
\hline $1400-1500$ & 0 & 48 & 1 & 36 & 18 & 16 & 28 & o & 1716 & - & 179 & 167 \\
\hline $1500-1600$ & 0 & 36 & 0 & 28 & 11 & 29 & 19 & 1 & 12 & 14 & 2 & 152 \\
\hline $1600-1700$ & 0 & 28 & 0 & 19 & 21 & 26 & 27 & 4 & 21 & II & 0 & 158 \\
\hline $1700-1800$ & 0 & 37 & o & 26 & 18 & 16 & 21 & 0 & 18 & 21 & 0 & 157 \\
\hline TOTAL & 1 & 396 & 2 & 317 & 139 & 277 & 319 & 31 & 242 & 241 & 28 & 1993 \\
\hline
\end{tabular}

DIRECTION INDICATORS FROM: OWO

\begin{tabular}{|c|c|c|c|c|c|c|c|c|c|c|c|c|}
\hline \multicolumn{10}{|c|}{ DIRECTION INDICATORS FROM: OWO } & \multicolumn{3}{|c|}{ TO: IKARE } \\
\hline $\begin{array}{l}\text { TIME } \\
\text { INTERVAL }\end{array}$ & BC & MC & TC & $\begin{array}{l}\text { CAR } \\
\text { (P) }\end{array}$ & PIUP & TXI & $\begin{array}{l}\text { OMAN } \\
\text { BUS }\end{array}$ & LEx & LOK/TKUCK & TRL/TANKEK & OTHER & TOTAL \\
\hline $0600-0700$ & o & 16 & o & 42 & 11 & 34 & 18 & 2 & 15 & 21 & 2 & 161 \\
\hline $0700-0800$ & 으 & 40 & 으 & 36 & 3 & 32 & 19 & 4 & 10 & 29 & 으 & 172 \\
\hline $0800-6900$ & 0 & 46 & 1 & 37 & 6 & 13 & 30 & 7 & $\overline{11}$ & 20 & 3 & 174 \\
\hline $0900-1000$ & o & 39 & o & 33 & 3 & 36 & 29 & 4 & 14 & 12 & 3 & 173 \\
\hline $1000-1100$ & 0 & 46 & 0 & 48 & 11 & 17 & 22 & 0 & 10 & 9 & 2 & 165 \\
\hline $1100-12000$ & 1 & 17 & 0 & 33 & 7 & 19 & 19 & 3 & 12 & 13 & 0 & 124 \\
\hline $1200-1300$ & 0 & 16 & 0 & 48 & 3 & 32 & 27 & 3 & 8 & 26 & 3 & 165 \\
\hline $1300-1400$ & $\circ$ & 25 & $\circ$ & 33 & 2 & 39 & 39 & 1 & 13 & 29 & 2 & 183 \\
\hline $1400-1500$ & 0 & 30 & 1 & 36 & o & 36 & 34 & 0 & 13 & 17 & 응 & 167 \\
\hline $1500-1600$ & 0 & 45 & 0 & 40 & 1 & 47 & 31 & 2 & 21 & 16 & 1 & 204 \\
\hline $1600-1700$ & 0 & 48 & $\circ$ & 22 & 4 & 33 & 37 & 6 & 11 & 9 & 4 & 174 \\
\hline $1700-1300$ & 0 & 36 & 0 & 33 & 1 & 39 & 33 & 2 & 19 & 17 & 1 & 180 \\
\hline TOTAL & 1 & 402 & 2 & 440 & 52 & 377 & 338 & 34 & 157 & 218 & 21 & 2042 \\
\hline
\end{tabular}

\begin{tabular}{|c|c|c|c|c|c|c|}
\hline & \multicolumn{3}{|c|}{$20134^{\text {th }}$ Quarter } & \multicolumn{3}{|c|}{$20141^{\text {st }}$ Quarter } \\
\hline Vehicle & Ikare/Owo & Owo/Ikare & Total & Ikare/Owo & Owo/Ikare & Total \\
\hline BC & 7 & 0 & 7 & 1 & 1 & 2 \\
\hline MC & 441 & 514 & 955 & 396 & 402 & 798 \\
\hline TC & 2 & 0 & 2 & 2 & 2 & 4 \\
\hline Car & 757 & 613 & 1370 & 317 & 440 & 757 \\
\hline $\mathbf{P} / \mathbf{U P}$ & 454 & 307 & 761 & 139 & 52 & 191 \\
\hline Taxi & 152 & 192 & 344 & 277 & 377 & 654 \\
\hline Omni Bus & 469 & 406 & 875 & 319 & 338 & 657 \\
\hline Luxury & 4 & 97 & 101 & 31 & 34 & 65 \\
\hline Lor/Truck & 176 & 132 & 308 & 242 & 157 & 399 \\
\hline Trailer/Tanker & 107 & 85 & 192 & 241 & 218 & 459 \\
\hline Other & 149 & 86 & 235 & 28 & 21 & 49 \\
\hline Total & 2718 & 2432 & 5150 & 1993 & 2042 & 4035 \\
\hline
\end{tabular}

Total traffic counted bi-directionally during the 2013 Fourth Quarter Traffic Count (before the speed bumps were installed) $=5150$ 
Total hour spent $=12$

Average vehicular traffic per hour $=$

total vehicular traffic counted bi-directionally

Total hour spent

Average vehicular traffic per hour $=5150 / 12$

$=429$ vehicles per hour

Total traffic counted bi-directionally during the 2014 First Quarter Traffic Count (after the speed bumps were installed) $=4035$

Total hour spent $=12$

Average vehicular traffic per hour $=$

total vehicular traffic counted bi-directionally

/Total hour spent

Average vehicular traffic per hour $=4035 / 12$

$\% \Delta$ in traffic pattern $=\begin{gathered}=336 \text { vehicles per hour } \\ (4035-5150) / 5150 \times 100 \%\end{gathered}$

$=-1115 / 5150^{\times 100 \%}$

$=-21.65 \%$

There was $21.65 \%$ decline in traffic volume when the 2013 Fourth Quarter Traffic Count Data (before the speed bumps installation) and 2014 First Quarter Traffic Count Data (after the speed bumps installation) collated with respect to Ikare-Owo route were compared. The decrease might be owing to motorists' alternative routes of getting to their various destinations. The peak period in the 2013 Fourth Quarter Traffic Count was in the morning $(0600 \mathrm{hrs}-0700 \mathrm{hrs})$ considering the route bi-directionally.

In the 2014 First Quarter Traffic Count, two (2) peak periods were recorded along the route since the highest number of traffic counted bi-directionally was 204. The peak period of Ikare-Owo was considered as the total traffic counted was less than that of Owo-Ikare. Therefore the period fell in the morning and reduces pedestrians (especially children) vulnerability as might have gone to schools in the areas close to the highway.

\section{Conclusion}

Effective traffic management in Nigeria is threatened not only by inadequacy of traffic engineering measures, but also by the poor road culture of the people. This does not allow many drivers and other road users to take note of existing measures; hence the obvious flagrant disregard of the safety measures. The Driving School Standardization Programme (DSSP) and the National Drivers' Training Manual developed by the FRSC under its Training, Standards and Certification arm were designed to address the preponderance of human errors leading to avoidable road mishaps in Nigeria. The Corps emphasizes that all driving schools in the country either owned by government or private individuals conform to the stipulated guidelines and specifications for the benefit of all (FRSC Report,2010). But how much are the procedures adhered to?

Pedestrians (mostly children) also contribute to road traffic crashes by not observing road traffic rules and regulations. Some pedestrians walk or run across the road without looking and ensuring the road is safe to do so while others do not wear reflective clothes at night so that drivers could easily see them. These behaviours contribute to road traffic crashes (FRSC, 2013b). Road safety education is said to be a potent tool for the prevention of RTCs and bringing in road safety curriculum into the normal school programme to inculcate them with road safety culture in a tender age, but "how much is it welcomed" becomes very significant.

This group of road users (i.e. pedestrians) is the primary purpose while speed bumps are installed in some locations. The erection of speed bumps without recourse to specifications posed danger to both vehicles and road users. As observed, people who are residence close to the highway are in the habit of indiscriminately erecting bumps without recourse to the concerned agency. These practices greatly undermine government's 
efforts at ensuring sanity on the roads. They do not take the interest of the society into account and there is the need for some level of control and regulation.

WHO and the Global Road Safety Partnership in the publication-Speed Management: a Road Safety Manual for Decisions Makers and Practitioners, 2008 recommended that speed limit should be introduced in every country as part of the global strategy to cut down road fatalities and according to COMACE, the Corps major challenge is enforcing traffic laws on over speeding without any bias or exceptions especially as it affects executive recklessness.

But insufficient database is the bane of traffic management in the country and poor political will hampered robust traffic data collation which would have aided the country in the overall safety and security. It is regrettable that comprehensive collaborative efforts of the FRSC with institutions towards enhancement of a safer traffic environment are paid deaf ear to or not embraced fully. Rather, road safety issues are approached unilaterally in different quarters. Hence, the continual deplorable trends of road traffic crashes in Nigeria.

\section{Recommendations}

Certain challenges militating against the maintenance of safety on the selected routes have been sufficiently identified above. To mitigate these challenges, the following recommendations are hereby suggested:

It is strongly advised that the recommendations being presented after the conduct of road safety audits should be accepted and followed to the letter and the implementation of the International Road Assessment Programme (iRAP) tools should be pursued with vigour as it assists in the identification of highest risk highways and enable the Ministry of Works to establish a targeted programme of interventions.

It is strongly recommended that close monitoring of the driving schools should be conducted at all time as it ensures proper driver training which would guaranteed crash free roads in Nigeria.

Pedestrians involved in RTCs are mostly children; it is recommended that adequate road safety knowledge should be imparted to them at the early stage to raise their consciousness level through full implementation of road safety education in the school curriculum by the school administrators.

It is also recommended that the Federal Roads Committee on Surveillance and Action against Road Abuse should be alive to its responsibility of prosecuting any person caught abusing the roads.

There should be strict enforcement of traffic laws on every traffic offender without care whose ox is gored i.e. there should be no exception to the compliance of the law and in the case of crash, the financial responsibilities/burdens of injured victims should be transferred to the driver/rider that caused it.

The fact that prevalent violations on these selected routes are speed dependant, it is also suggested that the decisions agreed on in a communique issued on the $2^{\text {nd }}$ Stakeholders' forum on speed limiting device enforcement in Nigeria held in Abuja on Wednesday 04 September 2013 should be given strong political backing to achieve the goal of tackling speed factor.

With credible database, accountability is ensured as traffic infractions recorded are traced to the offenders. Emphasis must be placed on data control and is achievable only and only if it is fully institutionalized through strong political will.

A stronger multi-sectoral collaboration on road safety should be encouraged amongst agencies and other Non-Governmental Organisations as safety on the roads is everybody's business.

\section{Acknowledgement}

I give thanks to the Almighty God for the inspiration and also my lovely wife, Mrs Taiye Elizabeth Richard for giving the moral supports. I must sincerely thank my Colleagues, YE Ojo; Fadumo and Ayanleke for assisting in the data gathering. Without forgetting the staff of the PRS Department in RS11.2 Ondo Sector Command for making vital information readily available and the entire Command for creating the enabling environment.

\section{References}

[1]. Ashton, S.J (1981). Pedestrian injuries: The influence of vehicle Design in H.C. Foot et al (ed.) Road Safety Research and Practice. Praeger,1981.

[2]. FRSC (2013a). FRSC and the Speed Burden. Retrieved April 10, 2014 from http://www.nigeriaintel.com/2013/09/21/frsc-and-thespeed-burden/

[3]. FRSC. 2013b. Nigeria Highway Code ( $3^{\text {rd }}$ edition).Abuja: Detailworks Publication. August 2013.

[4]. FRSC Report. 2010. Why we have road crashes. Retrieved April 13, 2014 from http://frsc.gov.ng/rtc2011.pdf, pp.64

[5]. Nantulya, V.M. and M.R. Reich, 2002. The neglected epidemic: Road traffic injuries in developing countries. Br. Med. J., 324: $1139-1141$

[6]. Odeleye, J.A. Improved Road Traffic Environment for Better Child Safety in Nigeria. $13^{\text {th }}$ ICTCT Workshop Pedestrians and Road Design Proceedings

[7]. Oguara, T. M. (2010), a Management Model for Road Infrastructure Maintenance. Book of proceedings, 19th engineering assembly, Council for the Regulation of Engineering in Nigeria. 
[8]. Omidiji, A.A. and Ibitoye, S.A.2010. Crime and Road Traffic Crashes Prevention in Public Transportation System in Nigeria: The Case Study of Kwara, Kogi and Ekiti States 24th ARRB Conference - Building on 50 years of road and transport research, Melbourne, Australia 2010

[9]. Omidiji, A.A.2010. Observational Studies of Road Traffic Engineering Measures on Federal Capital Territory Roads in Abuja, Nigeria. Proceedings of the $20^{\text {th }}$ Canadian Multidisciplinary Road Safety Conference, Niagara Falls, Ontario, June 6-9, 2010

[10]. Oyedepo, O.J. and Makinde, O.O.2010. Accident Prediction Models for Akure-Ondo Carriageway, Ondo State Southwest Nigeria; Using Multiple Linear Regressions. An International Multi-Disciplinary Journal, Ethiopia Vol. 4 (2) April, 2010 (Pp. 30-49)

[11]. Wikipedia.2013. Highway. $\quad$ Retrieved

$\begin{array}{lll}\text { February } 26, \quad 2014 & \text { from }\end{array}$

[12]. WHO. 2004. World Report on Road Traffic Injury Prevention. World Health Organization: Geneva, Switzerland. 